\title{
Equivalence Relations for the 9972-9975 SARP (U)
}

by

K. A. Niemer

Westinghouse Savannah River Company

Savannah River Site

Aiken, South Carolina 29808

R. L Frost

Westinghouse Savannah River Company

SC USA

DOE Contract No. DE-AC09-89SR18035

This paper was prepared in connection with work done under the above contract number with the U.S.

Department of Energy. By acceptance of this paper, the publisher and/or recipient acknowledges the U.S. Government's right to retain a nonexclusive, royalty-free license in and to any copyright covering this paper, along with the right to reproduce and to authorize others to reproduce all or part of the copyrighted paper.

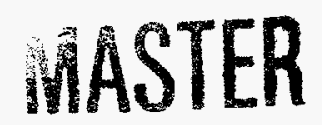


WSRC-TR-94-0366

\title{
EQUIVALENCE RELATIONS FOR THE 9972-9975 SARP (U)
}

\author{
By
}

\author{
KEYES A. NIEMER \\ ROBERT L. FROST
}

OCTOBER 1994

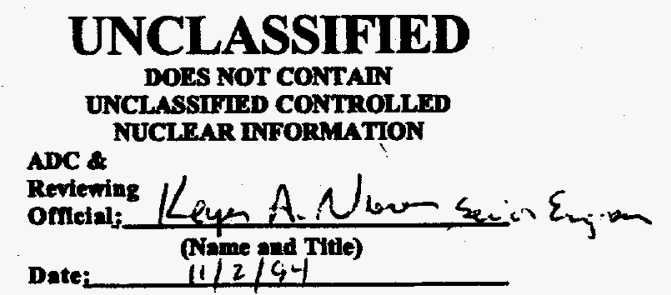

Westinghouse Savannah River Company

Savannah River Site

Aiken, SC 29808

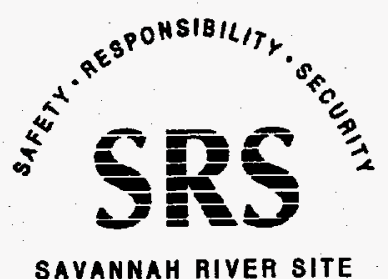




\section{DISCLAIMER}

This report was prepared as an account of work sponsored by an agency of the United States Government. Neither the United States Government nor any agency thereof, nor any of their employees, makes any warranty, express or implied, or assumes any legal liability or responsibility for the accuracy, completeness, or usefulness of any information, apparatus, product, or process disclosed, or represents that its use would not infringe privately owned rights. Reference herein to any specific commercial product, process, or service by trade name, trademark, manufacturer, or otherwise does not necessarily constitute or imply its endorsement, recommendation, or favoring by the United States Government or any agency thereof. The views and opinions of authors expressed herein do not necessarily state or reflect those of the United States Government or any agency thereof.

This report has been reproduced directly from the best available copy.

Available to DOE and DOE contractors from the Office of Scientific and Technical Information, P.O. Box 62, Oak Ridge, TN 37831; prices available from (615) 576-8401.

Available to the public from the National Technical Information Service, U.S. Department of Commerce, 5285 Port Royal Road, Springfield, VA 22161. 


\section{DISCLAIMER}

Portions of this document may be illegible in electronic image products. Images are produced from the best available original document. 
WSRC-TR-94-0366

KEY WORDS:

SAFETY ENGINEERING DEPARTMENT
Equivalence Relations

Rule-of-Fractions

Criticality

Shielding

Permanent

EQUIVALENCE RELATIONS FOR THE 9972-9975 SARP (U)

By

KEYES A. NIEMER

ROBERT L. FROST

ISSUED: OCTOBER 1994

WESTINGHOUSE SAVANNAH RIVER COMPANY, AIKEN, SC 29808

Prepared for the U. S. Department of Energy under Contract DE-AC0988SR18035 
DOCUMENT:

TITLE:

TASK:

TASK TITLE:
WSRC-TR-94-0366

EQUIVALENCE RELATIONS FOR THE 9972-9975 SARP (U)

93-006-H-W-1

FISSILE MATERIAL PACKAGING CRITICALITY

APPROVALS

Q.7. w. Tarlame

A. McFARLANE, MANAGER CRITICALITY AND FIRE ANALYSIS SECTION

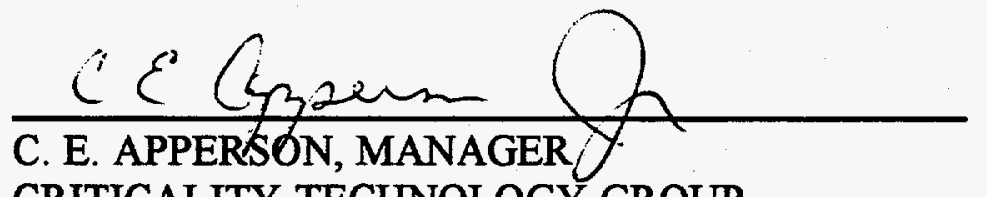

CRITICALITY TECHNOLOGY GROUP

T.6. Villlansor

T. G. WILLIAMSON, TECHNICAL REVIEWER

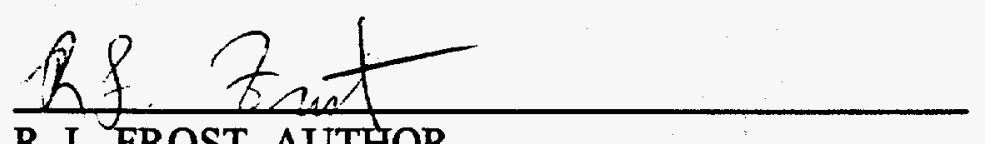

R. L. FROST, AUTHOR

Leper. Nevi

K. A. NIEMER, AUTHOR

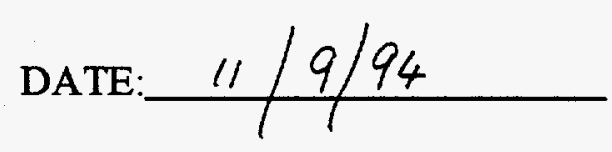

DATE: $11-6-94$

DATE: $\quad 11 / 4 / 94$

DATE: $11 / 2 / 94$

DATE: $10 / 31 / 94$ 


\section{ABSTRACT}

Equivalence relations required to determine mass limits for mixtures of nuclides for the Safety Analysis Report for Packaging (SARP) of the Savannah River Site 9972, 9973, 9974, and 9975 shipping casks were calculated. The systems analyzed included aqueous spheres, homogeneous metal spheres, and metal ball-and-shell configurations, all surrounded by an effectively infinite stainless steel or water reflector. Comparison of the equivalence calculations with the rule-offractions showed conservative agreement for aqueous solutions, both conservative and nonconservative agreement for the metal homogenous sphere systems, and non-conservative agreement for the majority of metal ball-and-shell systems. Equivalence factors for the aqueous solutions and homogeneous metal spheres were calculated. The equivalence factors for the nonconservative metal homogeneous sphere systems were adjusted so that they were conservative. No equivalence factors were calculated for the ball-and-shell systems since the SARP assumes that only homogeneous or uniformly distributed material will be shipped in the 9972-9975 shipping casks, and an unnecessarily conservative critical mass may result if the ball-and-shell configurations are included. 


\section{Table of Contents}

Page

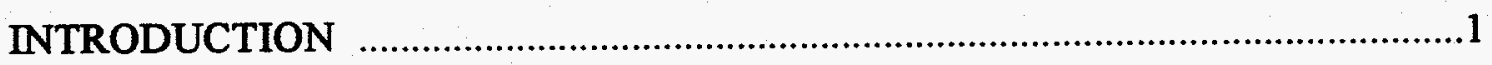

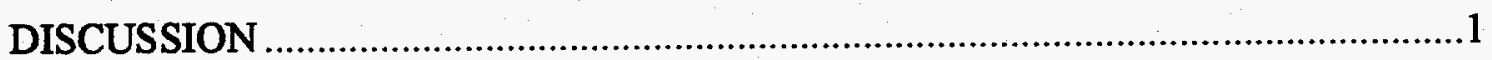

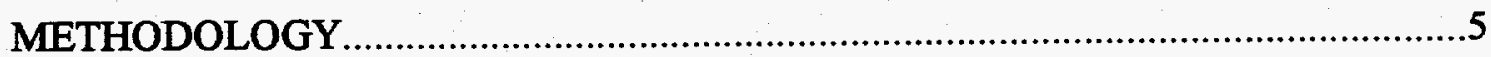

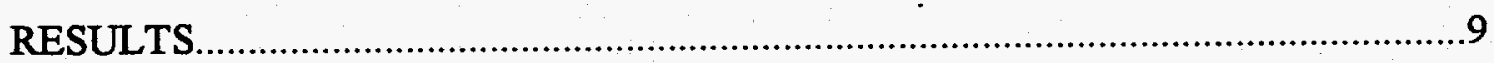

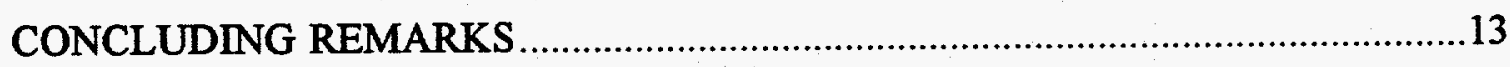

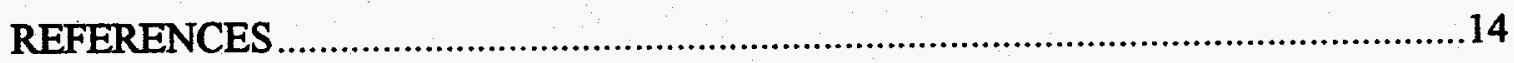

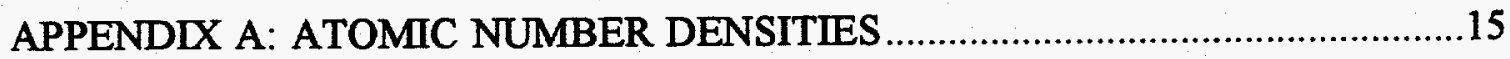

APPENDIX B: DATA FOR MIXTURES WITH $\mathrm{H}_{2} \mathrm{O}$ REFLECTOR .......................18

APPENDIX C: DATA FOR MIXTURES WITH STAINLESS

STEEL REFLECTOR 


\section{INTRODUCTION}

Equivalence relations based on the rule-of-fractions method have been used for some time in criticality analysis. These relations are useful because they allow determination of critically safe masses for a combination of fissile and/or fissionable nuclides based on the critically safe mass of a reference isotope. However, equivalence relations have not previously been applied to shipping cask criticality analysis. Previous applications of equivalence relations have been restricted to binary systems of isotopes. This report describes a study of equivalence relations for several higher order systems representative of fuel to be shipped in the 9972-9975 series of shipping casks. The equivalence relations developed here are used in the determination of critically safe masses of each fuel type.

The shipment of fissionable materials is regulated by the NRC, 10 CFR 71.1 In past permit applications, relatively simple fuel content descriptions were used for various reasons:

1. In order to be conservative, no credit was taken for fission products when shipping spent nuclear fuel.

2. For ease of analysis, shipments within the weapons complex containing ${ }^{235} \mathrm{U}$ and/or ${ }^{239} \mathrm{Pu}$ with other actinide isotopes were analyzed simply as containing ${ }^{235} \mathrm{U}$ and/or ${ }^{239} \mathrm{Pu}$.

In the current regulatory environment, it is not acceptable to ignore the other actinide isotopes; their contribution to the system reactivity must be known. The fuel to be shipped in the 99729975 series of shipping casks spans a wide range of actinide isotopes with sliding envelopes of content ranges. For instance, one envelope contains $0-95 \%{ }^{239} \mathrm{Pu}, 0-50 \%{ }^{240} \mathrm{Pu}, 0-2 \%{ }^{241} \mathrm{Pu}$,

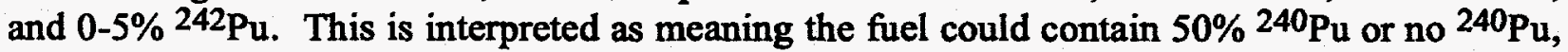
etc. There are 13 such content envelopes (only six are discussed in this report), and 4 different shipping casks to be analyzed. Direct calculations to find the most limiting cases would be a tremendously complex task. Instead, equivalence relations can be developed for the other isotopes using $235 \mathrm{U}$ and $239 \mathrm{Pu}$ as reference isotopes. The criticality analysis can then be performed for ${ }^{235} \mathrm{U}$ and ${ }^{239} \mathrm{Pu}$ only, and the safe fuel envelope masses can be determined from the equivalence relations. This report discusses the development of the appropriate equivalence relations for the $9972-9975$ series of shipping casks. ${ }^{2}$

\section{DISCUSSION}

Fissile material to be shipped in the $9972-9975$ series of shipping casks originates from several different sources. The material to be shipped can be delineated into six ${ }^{a}$ isotopic content envelopes as shown in Table 1. Equivalence relations were developed to determine safe mass limits for each of the content envelopes based on safe masses of the reference isotopes ${ }^{235} \mathrm{U}$ and ${ }^{239} \mathrm{Pu}$.

a There are actually 13 content envelopes, but only six have been considered to date. 
Equivalence relations are based on the rule-of-fractions from American National Standard ANSI/ANS-8.15, Section 5.2, which states that the sum of the ratios of the mass of each fissile nuclide to its limit does not exceed unity for well-moderated, water-reflected systems. ${ }^{3}$ The rule can be extended to fast systems by adjusting the equivalence value as demonstrated in this report. The rule-of-fractions can be expressed as follows:

$$
\sum_{i} \frac{m_{i}}{M_{i}} \leq 1.0
$$

where $m_{i}$ is the mass of nuclide $i$, and $M_{i}$ is the mass limit of nuclide $i$. Equation 1 can be rewritten using equivalence factors, $E F_{i}$, such that the mass of different nuclides in a mixture multiplied by an equivalence factor will be less than or equal to the mass limit of a reference nuclide, $M$ :

$$
\sum_{i} E F_{i}^{*} m_{i} \leq M
$$

where $E F_{i}=\frac{M}{M_{i}}$.

For example, with two nuclides $A$ and $B$, the rule-of-fractions is expressed as 4

$$
\frac{m_{A}}{M_{A}}+\frac{m_{B}}{M_{B}} \leq 1.0
$$

which can be rewritten as

$$
m_{A} \frac{M_{B}}{M_{A}}+m_{B} \leq M_{B}
$$

Using an equivalence factor, $E F_{A}$, and $B$ as the reference nuclide, equation 5 becomes

$$
m_{A} E F_{A}+m_{B} \leq M_{B}
$$

where $E F_{A}=\frac{M_{B}}{M_{A}}$.

The implication of using an equivalence relation is that the multiplication factor is not increased when the mixture is formed. 4

Previous studies 4 have demonstrated that the rule-of-fractions is a good estimate of the reactivity of binary mixtures if they are well-moderated and water-reflected. For fast systems, a plot of $k_{\text {eff }}$ versus concentration of one of the isotopes follows two possible scenarios: 1) all mixture $k_{\text {eff }} s$ 
fall below the rule-of-fractions line (Figure 1), or 2) all mixture $k_{\text {eff }}$ 's lie above the rule-of-fractions line (Figure 2). The rule-of-fractions is conservative with respect to the first scenario and nonconservative with respect to the second. In the latter case, the equivalence value can be increased until the highest point on the curve of $k_{\text {eff }}$ versus concentration falls below the rule-of-fractions line, as demonstrated in Figure 2. This is the technique employed in the current work.

Table 1. Isotopic ranges of cases analyzed. ${ }^{b}$

\begin{tabular}{|c|l|c|c|c|c|c|c|}
\hline & & \multicolumn{7}{|c|}{ Weight \% of Isotopes } \\
\cline { 3 - 7 } Isotope & & Case 1 & Case 2 & Case 3 & Case 4 & Case 5 & Case 6 \\
\hline${ }^{235} \mathrm{U}$ & Fissile & 0 & 0 & $0-95$ & 0 & 0 & $0-100$ \\
${ }^{236} \mathrm{U}$ & Fissionable & 0 & 0 & 0 & 0 & 0 & $0-40$ \\
${ }^{238} \mathrm{U}$ & Fissionable & 0 & 0 & $0-100$ & 0 & 0 & $0-100$ \\
${ }^{238} \mathrm{Pu}$ & Fissionable & 0 & 0 & 0 & $0-100$ & 0 & 0 \\
${ }^{239} \mathrm{Pu}$ & Fissile & $0-95$ & $0-95$ & $0-100$ & $0-40$ & $0-95$ & 0 \\
${ }^{240} \mathrm{Pu}$ & Fissionable & $0-50$ & $0-50$ & $0-50$ & $0-13$ & $0-50$ & 0 \\
${ }^{241} \mathrm{Pu}$ & Fissile & $0-2$ & $0-2$ & $0-2$ & $0-1$ & $0-2$ & 0 \\
${ }^{242} \mathrm{Pu}$ & Fissionable & $0-5$ & $0-5$ & $0-5$ & $0-1.5$ & $0-5$ & 0 \\
${ }^{241} \mathrm{Am}$ & Fissionable & $0-5$ & $0-50$ & 0 & 0 & $0-5$ & 0 \\
\hline
\end{tabular}

\footnotetext{
b For each isotope, the maximum weight percent that could be contained in each packaging group is listed. Thus, the total percentages for each group sum to more than $100 \%$. When finding the mass limits for a particular content group, the most reactive combination of isotopes that sum to $100 \%$ was used. The contents listed in this table are only those considered important for the criticality analysis. Several other fissionable isotopes are not listed because the maximum weight percentages of those isotopes result in extremely small isotopic masses. For example, content groups $1-5$ allow a maximum of $1 \times 10^{-4} \mathrm{wt}$. $\%$ of ${ }^{243} \mathrm{Am}$. The maximum mass limit for these content groupings is $4.4 \mathrm{~kg}$, which results in an ${ }^{243} \mathrm{Am}$ mass less than $0.44 \mathrm{~g}$, an inconsequential quantity when compared to ${ }^{243} \mathrm{Am}$ 's critical mass of $54 \mathrm{~kg}$ (bare) and $36 \mathrm{~kg}$ (stainless steel reflected).
} 


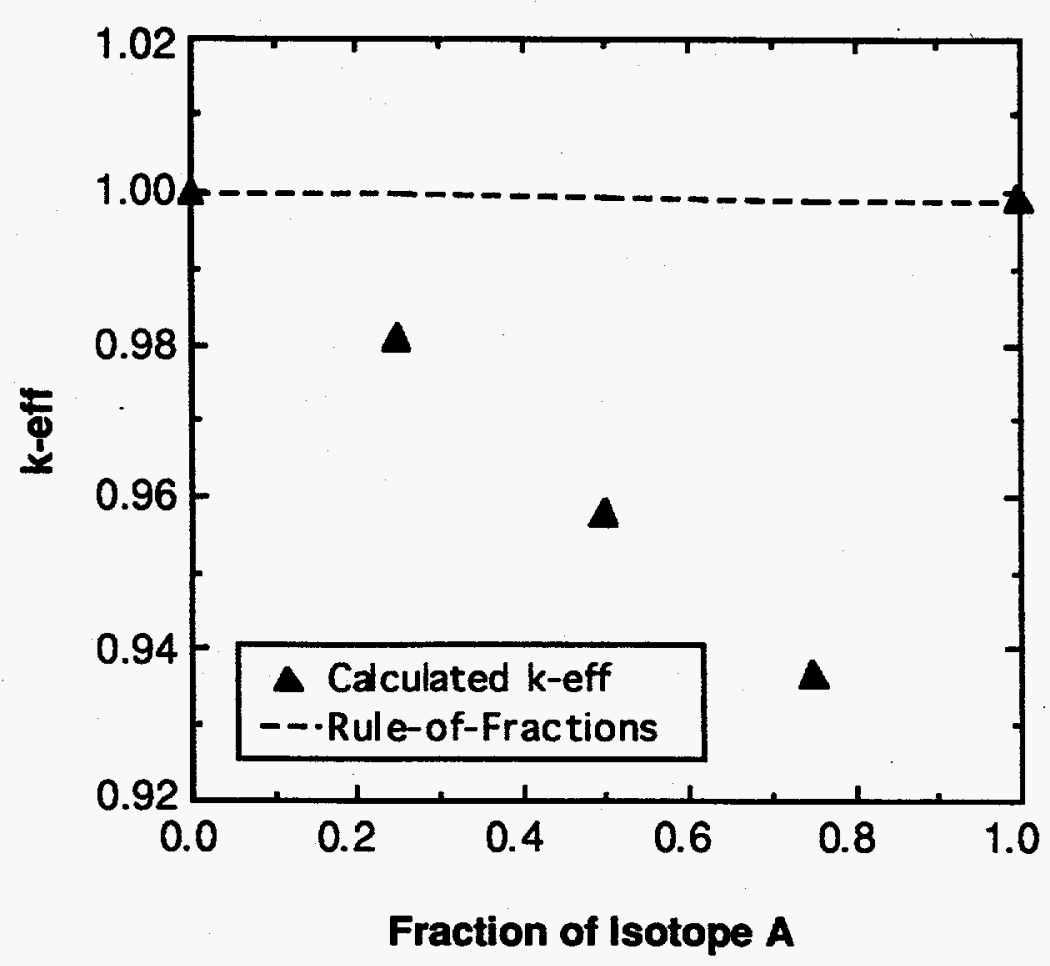

Figure 1. Example of conservative case with calculated $k_{\text {eff's falling below the rule-of-fractions }}$ line.

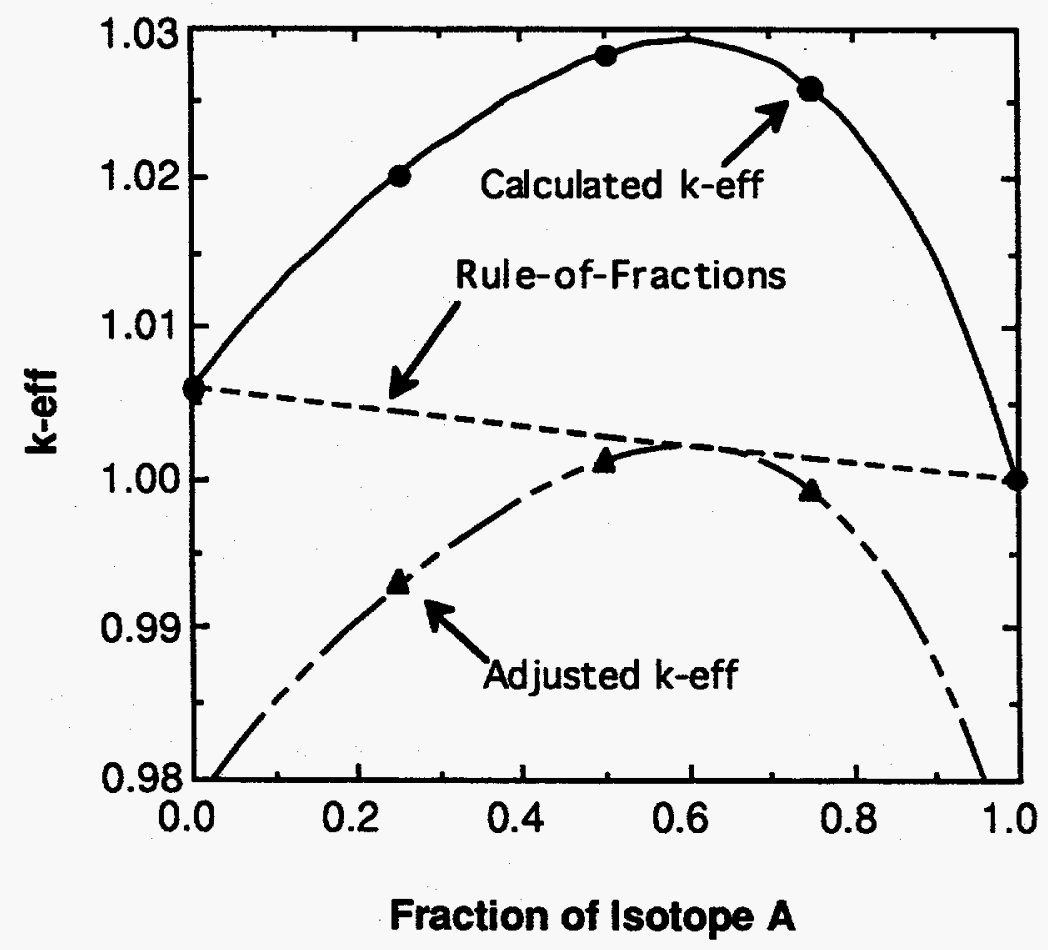

Figure 2. Example of non-conservative case with calculated $k_{\text {eff }}$ 's lying above the rule-of-fractions line. 


\section{METHODOLOGY}

Equivalence relations were calculated using the LAW 44-energy group cross section library, developed at Oak Ridge National Laboratory 5 and based on ENDF/B-V and VI data. The LAW 44-energy group library was validated at SRS for relevant systems and isotopes in the SARP work. ${ }^{6-9}$ For this equivalence analysis, the cross sections were processed with the AJAX, BONAMI, NITAWL, and ALPO modules of the AMPX-7710 modular code system to create an ANISN library. In thermal systems where resonance overlap was a concern, the ROLAIDS module was used in place of the BONAMI and NITAWL modules for resonance processing. The ANISN library was used by the ONEDANT module of TWODANT-SYS ${ }^{11}$ to compute eigenvalues for each mixture. Equivalence factors for these mixtures were calculated such that the rule-of-fractions guaranteed a conservative result.

Table 2 lists the isotopes and type of systems analyzed. Equivalence factors based on binary mixtures were calculated and are expected to hold for higher order systems. The first step in calculating equivalence factors for different mixtures was to compute the critical mass of each isotope. One-dimensional spherical models of the metal and aqueous systems were prepared. The models consisted of a fissile core (either metal or aqueous) surrounded by a $20-\mathrm{cm}$ thick reflector (a water reflector for one set of equivalence factors and a stainless steel reflector for a second set of equivalence factors). The critical mass of each individual isotope was computed using a dimension search to vary the radius of the fissile core while keeping the thickness of the reflector region constant. A constant $k_{\text {eff }}$ was used in the ONEDANT dimension search. For ${ }^{235} \mathrm{U}$ and ${ }^{239} \mathrm{Pu}$, the bias adjusted $\mathrm{k}_{\text {eff }}$ from previous validation work was used in the search.6-8 For the other isotopes, $a k_{\text {eff }}$ of 1.0 was used in the search since no validation data were available.

After calculating the critical mass of each isotope, binary mixtures were formed based on equation 4. Mixtures were formed using fractions of the isotopes' critical mass such that the sum of the fractions equaled 1.0:

$$
f_{A}+f_{B}=1.0
$$

where

and

$$
f_{A}=\frac{m_{A}}{M_{A}}
$$

$$
f_{B}=\frac{m_{B}}{M_{B}}
$$

Note that $f_{A}$ and $f_{B}$ are not weight fractions of the isotopes in the mixture; they are the fraction of the critical mass of isotopes A and B.

Five combinations of $f_{A}$ and $f_{B}$ were formed for the aqueous and metal homogeneous systems (Table 3). Two endpoints were formed consisting of $100 \%$ of the critical mass of each isotope (isotopes A and B), and three intermediate mixtures were formed consisting of: 1) $25 \%$ of the 
critical mass of isotope $\mathrm{A}\left(f_{A}=0.25\right)$ and $75 \%$ of the critical mass of isotope $\left.\mathrm{B}\left(f_{B}=0.75\right), 2\right) 50 \%$ of the critical mass of isotope $A\left(f_{A}=0.50\right)$ and $50 \%$ of the critical mass of isotope $B\left(f_{B}=0.50\right)$, and finally 3) $75 \%$ of the critical mass of isotope $A\left(f_{A}=0.75\right)$ and $25 \%$ of the critical mass of the isotope $\mathrm{B}\left(f_{B}=0.25\right)$. Four combinations of $f_{A}$ and $f_{B}$ were formed for the metal ball-and-shell systems (Table 4). Two endpoints were formed consisting of $100 \%$ of the critical mass of each isotope. One intermediate point was formed consisting of $50 \%$ of the critical mass of isotope A $\left(f_{A}=0.50\right)$ as the ball and $50 \%$ of the critical mass of isotope $B\left(f_{B}=0.50\right)$ as the shell. A second intermediate point was similarly formed using isotope $B\left(f_{B}=0.50\right)$ as the ball and isotope $A$ $\left(f_{A}=0.50\right)$ as the shell. The mass, $m$, of each isotope in the mixture was calculated using equations 9 and 10. The radius of the mixture and atomic number density of the isotopes were then calculated from $m$ as shown in Appendix A.

All mixtures were modeled as either aqueous spheres, homogeneous metal spheres, or metal balland-shell configurations. The aqueous systems were surrounded by a 20 - $\mathrm{cm}$ thick water reflector, and the metal systems were surrounded by either a $20-\mathrm{cm}$ thick stainless steel (type 304) or water reflector. The LAW cross sections were processed with the appropriate AMPX77 modules to generate an ANISN library for each mixture. The ANISN library was used by ONEDANT to compute eigenvalues for each mixture using $S_{8}$ quadrature and $P_{3}$ Legendre scattering, which was consistent with previous validation work. ${ }^{6-9}$

Since the rule-of-fractions is defined for aqueous solutions and slurries, it had to be validated for the metal systems. Therefore, the computed $\mathrm{k}_{\text {eff }}$ for each mixture was compared to the expected rule-of-fractions value. If the computed $\mathrm{k}_{\text {eff }}$ was less than or equal to the rule-of-fractions value, then the rule-of-fractions was conservative for that system (Figure 1), and the equivalence factor was calculated using equation 7 . However, if the computed $k_{\text {eff }}$ was greater than the rule-offractions value (Figure 2), then the mass limit for the nonreference nuclide was reduced until the maximum computed $\mathrm{k}_{\text {eff }}$ was less than the rule-of-fractions value. For this case, the equivalence factor for the mixture was computed as follows:

$$
E F_{A}=\frac{M_{B}}{M_{A}^{\prime}}
$$

where $M_{A}^{\prime}$ is the reduced mass limit for the nonreference nuclide. 
Table 2. Isotopes and type of systems analyzed.

\begin{tabular}{|c|l|}
\hline Isotopes & \multicolumn{1}{|c|}{ Type of System } \\
\hline${ }^{235 U-239} \mathrm{Pu}$ & $\begin{array}{l}\text { Aqueous Spherec } \\
\text { Metal Homogeneous Sphere } \\
\text { Metal Ball-and-Shell }\end{array}$ \\
\hline${ }^{235} \mathrm{U}-240 \mathrm{Pu}$ & $\begin{array}{l}\text { Metal Homogeneous Sphere } \\
\text { Metal Ball-and-Shell }\end{array}$ \\
\hline${ }^{239} \mathrm{Pu}-238 \mathrm{Pu}$ & $\begin{array}{l}\text { Metal Homogeneous Sphere } \\
\text { Metal Ball-and-Shell }\end{array}$ \\
\hline${ }^{239} \mathrm{Pu}-240 \mathrm{Pu}$ & $\begin{array}{l}\text { Metal Homogeneous Sphere } \\
\text { Metal Ball-and-Shell }\end{array}$ \\
\hline${ }^{239} \mathrm{Pu}-241 \mathrm{Pu}^{\mathrm{d}}$ & $\begin{array}{l}\text { Aqueous Spherec } \\
\text { Metal Homogeneous Sphere }\end{array}$ \\
\hline${ }^{239} \mathrm{Pu}-242 \mathrm{Pu}^{\mathrm{d}}$ & Metal Homogeneous Sphere \\
\hline${ }^{239} \mathrm{Pu}-241 \mathrm{Am}$ & $\begin{array}{l}\text { Metal Homogeneous Sphere } \\
\text { Metal Ball-and-Shell }\end{array}$ \\
\hline
\end{tabular}

c The aqueous sphere system was only analyzed for cases which could contain a mixture of two fissile nuclides. All the other cases contain mixtures of fissile and fissionable nuclides. Aqueous mixtures of fissile and fissionable nuclides will be less reactive than an aqueous solution of the fissile nuclide alone.

d These mixtures were analyzed after all the other mixtures were analyzed; based on the previous analyses, it was determined that no equivalence factors would be calculated for the ball-and-shell systems since the SARP assumes that only homogeneous or uniformly distributed material will be shipped in the 9972-9975 shipping casks, and an unnecessarily conservative critical mass may result if the ball-and-shell configurations are included. Thus no balland-shell systems were analyzed for these mixtures. 
Table 3. Percentage of critical mass of isotopes in aqueous and metal homogeneous mixtures.

\begin{tabular}{|l|c|c|}
\hline Mixture & $\begin{array}{c}f_{A} \\
\text { Fraction of Isotope A } \\
\text { Critical Mass }\end{array}$ & $\begin{array}{c}f_{B} \\
\text { Fraction of Isotope B } \\
\text { Critical Mass }\end{array}$ \\
\hline 1 (endpoint) & 0 & 1.00 \\
2 (intermediate) & .25 & .75 \\
3 (intermediate) & .50 & .50 \\
4 (intermediate) & .75 & .25 \\
5 (endpoint) & 1.00 & 0 \\
\hline
\end{tabular}

Table 4. Percentage of critical mass of isotopes in metal ball-and-shell mixtures.

\begin{tabular}{|c|c|c|c|}
\hline Mixture & Description & $\begin{array}{c}f_{A} \\
\text { Fraction of Isotope A } \\
\text { Critical Mass } \\
\end{array}$ & $\begin{array}{c}f_{B} \\
\text { Fraction of Isotope B } \\
\text { Critical Mass } \\
\end{array}$ \\
\hline 1 (endpoint) & Isotope $A$ is $B$ all & 0 & 1.00 \\
\hline 2 (intermediate) & $\begin{array}{l}\text { Isotope } \mathrm{A} \text { is Ball / } \\
\text { Isotope } \mathrm{B} \text { is Shell }\end{array}$ & .50 & .50 \\
\hline 3 (intermediate) & $\begin{array}{l}\text { Isotope B is Ball/ } \\
\text { Isotope A is Shell }\end{array}$ & .50 & .50 \\
\hline 4 (endpoint) & Isotope B is Ball & 1.00 & 0 \\
\hline
\end{tabular}




\section{RESULTS}

Equivalence relations for five isotopic content ranges of nuclides were calculated. The ranges correspond to Cases 1-5 in Table 1. Case 6 was dismissed since it contained only uranium, and the limits for these isotopes could be obtained from references for natural and enriched uranium. ${ }^{12}$ The systems analyzed included aqueous spheres, homogeneous metal spheres, and metal ball-and-shell configurations, all surrounded by an effectively infinite stainless steel or water reflector.

The fission spectrum, $\chi$, has a significant effect on the computed $\mathbf{k}_{\text {eff }}$ for the metal systems. A composite $\chi$ for each mixture was produced by weighting the $\chi$ 's for each isotope based on a fission rate, $v \Sigma_{f} \phi$, weighting. For each mixture, ONEDANT was first executed to calculate the $v \Sigma_{f} \phi$ for each isotope using the $\chi$ for one of the isotopes in the mixture. The computed $v \Sigma_{f} \phi$ 's were then normalized and used to weight the $\chi$ 's for each isotope to form a composite $\chi$ for the mixture. ONEDANT was then re-executed with the composite $\chi$, and the $v \Sigma_{f} \phi^{\prime} s$ calculated with the composite $\chi$ were verified to ensure that the weighting had not changed with the composite $\chi$.

Tables 5 and 6 list the critical radii and the critical masses for the isotopes considered. These values were used in computing the $\mathrm{k}_{\text {eff }}$ 's and rule-of-fractions values for all the cases using both a water and stainless steel reflector. Appendix $B$ lists the calculated $k_{e f f}$ 's, the rule-of-fractions values, and the differences between the $k_{\text {eff }}$ and rule-of-fractions values for all mixtures with a $\mathrm{H}_{2} \mathrm{O}$ reflector; and Appendix $\mathrm{C}$ lists the same information for mixtures with a stainless steel reflector. Comparison of the computed $k_{\text {eff' }}$ ' with the rule-of-fractions values showed conservative agreement for aqueous solutions; both conservative and non-conservative agreement for the metal homogenous sphere systems, which was not surprising since the rule-of-fractions is defined for aqueous solutions or slurries, ${ }^{3}$ and non-conservative agreement for the majority of the metal ball-and-shell systems.

For the conservative aqueous solutions and conservative homogeneous metal systems, the equivalence factors were calculated using equation 7 . For the non-conservative homogeneous metal systems, the mass limit of the nonreference nuclide was reduced until the maximum computed $\mathrm{k}_{\text {eff }}$ was less than the rule-of-fractions value, and the equivalence factors were calculated using equation 11.

Table 7 and 8 list the mass limits and the equivalence factors for the cases with aqueous spheres, and Tables 9 and 10 list the mass limits and the equivalence factors for the cases with homogenous metal spheres.

As stated above, the majority of cases with metal ball-and-shell configurations were found to be non-conservative. The rule-of-fractions grossly underpredicted $k_{\text {eff }}$ for ball-and-shell configurations when a plutonium isotope formed the ball part of the system. The ability of TWODANT and the LAW 44-energy group library to accurately calculate eigenvalues for these systems was verified by modeling critical experiments. 8,9 In fact, the critical experiments showed that the critical mass of a metal plutonium ball - uranium shell system is less than the critical 
mass of a uranium or plutonium system alone. ${ }^{8,9}$ Thus the results observed in this work are consistent with experiments. In order for a ball-and-shell configuration to be credible, the fissile fuel must be very heterogeneous and must consist of large pieces of which at least one is a concave surface. Three types of solid fuel are to be shipped in the 9972-9975 shipping casks: loose oxide powders, ash, and metal. Only the metal is a concern for a ball-and-shell configuration. Of the six content envelopes listed in Table 1, only cases 5 and 6 represent materials in metallic form. Case 6 contains only uranium isotopes and can be dismissed, but case 5 is a potential concern since it contains ${ }^{239} \mathrm{Pu},{ }^{240} \mathrm{Pu}$, and ${ }^{241} \mathrm{Am}$. However, the fuel corresponding to case 5 consists of metal pieces (about $2.2 \mathrm{~kg}$ each), two of which will be loaded into a single shipping cask. The pieces have a uniform isotopic distribution and are not concave. Thus, the ball-and-shell configuration is not relevant for the 9972-9975 shipping casks, and no equivalence factors for ball-and-shell configurations were calculated for this work. Note that if ball-and-shell configurations were considered, unnecessarily conservative critical masses would result. Potential users of the equivalence factors listed in this report are advised to confirm that ball-and-shell configurations are not relevant to their process. Revised equivalence factors are required if ball-and-shell systems (or systems that approximate them, such as two adjacent plates each of different isotopic composition) are considered. 
Table 5. Critical radii and masses for isotopes in aqueous mixture with $20-\mathrm{cm} \mathrm{H}_{2} \mathrm{O}$ reflector.

\begin{tabular}{|l|c|c|}
\hline \multicolumn{1}{|c|}{ Isotope } & Critical Radii (cm) & Critical Mass (g) \\
\hline${ }^{235} \mathrm{U}^{\mathrm{f}}$ & 15.07 & 774.68 \\
${ }^{239} \mathrm{Pu}^{\mathrm{f}}$ & 15.93 & 508.82 \\
${ }^{241} \mathrm{Pu}^{\mathrm{f}}$ & 12.98 & 275.01 \\
\hline
\end{tabular}

Table 6. Calculated critical radii and masses for isotopes in metal systems with either a 20-cm $\mathrm{H}_{2} \mathrm{O}$ reflector or a 20-cm type 304 stainless steel reflector.

\begin{tabular}{|l|c|c|c|c|}
\hline \multirow{2}{*}{ Isotope } & \multicolumn{2}{|c|}{ Critical Radii (cm) } & \multicolumn{2}{c|}{ Critical Mass (kg) } \\
\cline { 2 - 5 } & $\begin{array}{c}\mathrm{H}_{2} \mathrm{O} \\
\text { Reflector }\end{array}$ & $\begin{array}{c}\text { Stainless } \\
\text { Steel } \\
\text { Reflector }\end{array}$ & $\begin{array}{c}\dot{\mathrm{H}}_{2} \mathrm{O} \\
\text { Reflector }\end{array}$ & $\begin{array}{c}\text { Stainless } \\
\text { Steel } \\
\text { Reflector }\end{array}$ \\
\hline${ }^{235 \mathrm{U}}$ & 6.49 & 6.13 & 21.52 & 18.15 \\
$238 \mathrm{Pu}$ & 4.47 & 3.86 & 7.41 & 4.77 \\
${ }^{239} \mathrm{Pu}$ & 4.03 & 3.82 & 5.45 & 4.62 \\
${ }^{240} \mathrm{Pu}$ & 7.18 & 6.07 & 30.84 & 18.72 \\
$241 \mathrm{Pu}$ & 4.07 & 3.96 & 5.67 & 5.22 \\
$242 \mathrm{Pu}$ & 9.43 & 7.92 & 70.53 & 41.77 \\
$241 \mathrm{Am}$ & 11.58 & 9.83 & 89.13 & 54.47 \\
\hline
\end{tabular}

Table 7. Mass limits and equivalence factors for aqueous mixtures with ${ }^{235} \mathrm{U}$ as the reference nuclide. $\mathrm{g}$

\begin{tabular}{|c|c|c|}
\hline \multirow{2}{*}{ Isotope } & Mass Limit (g) & Equivalence Factor \\
\cline { 2 - 3 } & $\mathrm{H}_{2} \mathrm{O}^{\text {h }}$ Reflector & $\mathrm{H}_{2} \mathrm{O}^{\text {h }}$ Reflector \\
\hline${ }^{235} \mathrm{U}$ & 774.68 & 1.00 \\
$239 \mathrm{Pu}$ & 508.82 & 1.53 \\
\hline
\end{tabular}

\footnotetext{
The aqueous sphere was only analyzed with a $\mathrm{H}_{2} \mathrm{O}$ reflector because the critical values calculated for an aqueous solution with an $\mathrm{H}_{2} \mathrm{O}$ reflector are more conservative than those calculated with a stainless steel reflector.

f $235 \mathrm{U}$ critical radius and mass based on ${ }^{235} \mathrm{U}$ concentration of $54 \mathrm{~g} /$, which corresponds to the minimum critical mass for homogenous water-moderated ${ }^{235} \mathrm{U}$ spheres. ${ }^{13}{ }^{239} \mathrm{Pu}$ and ${ }^{241} \mathrm{Pu}$ critical radii and masses based on $\mathrm{Pu}$ concentration of $30 \mathrm{~g} / \mathrm{l}$, which corresponds to the minimum critical mass for homogenous water-moderated $\mathrm{Pu}$ spheres. ${ }^{13}$

$\mathbf{g}$ No limits or equivalence factors were developed for the ball-and-shell geometries.

h A 20-cm thick water reflector.
} 
Table 8. Mass limits and equivalence factors for aqueous mixtures with ${ }^{239} \mathrm{Pu}$ as the reference nuclide. 8

\begin{tabular}{|c|c|c|}
\hline \multirow{2}{*}{ Isotope } & Mass Limit (g) & Equivalence Factor \\
\cline { 2 - 3 } & $\mathrm{H}_{2} \mathrm{O}^{\mathrm{h}}$ Reflector & $\mathrm{H}_{2} \mathrm{O}^{\mathrm{h}}$ Reflector \\
\hline${ }^{239} \mathrm{Pu}$ & 508.82 & 1.00 \\
${ }^{241 \mathrm{Pu}}$ & 275.01 & 1.86 \\
\hline
\end{tabular}

Table 9. Mass limits and equivalence factors for metal homogeneous mixtures with $235 \mathrm{U}$ as the reference nuclide. $\mathrm{g}$

\begin{tabular}{|l|c|c|c|c|}
\hline \multirow{2}{*}{ Isotope } & \multicolumn{2}{|c|}{ Mass Limit (kg) } & \multicolumn{2}{c|}{ Equivalence Factor } \\
\cline { 2 - 5 } & $\begin{array}{c}\mathrm{H}_{2} \mathrm{O}^{\mathrm{h}} \\
\text { Reflector }\end{array}$ & $\begin{array}{c}\mathrm{SS}^{\mathrm{i}} \\
\text { Reflector }\end{array}$ & $\begin{array}{c}\mathrm{H}_{2} \mathrm{O}^{\mathrm{h}} \\
\text { Reflector }\end{array}$ & $\begin{array}{c}\mathrm{SS}^{\mathrm{i}} \\
\text { Reflector }\end{array}$ \\
\hline${ }^{235 \mathrm{U}}$ & 21.52 & 18.15 & 1.00 & 1.00 \\
${ }^{239} \mathrm{Pu}$ & 5.45 & 4.62 & 3.95 & 3.93 \\
$240 \mathrm{Pu}$ & 20.00 & 14.40 & 1.08 & 1.27 \\
\hline
\end{tabular}

Table 10. Mass limits and equivalence factors for metal homogeneous mixtures with ${ }^{239} \mathrm{Pu}$ as the reference nuclide.g

\begin{tabular}{|c|c|c|c|c|}
\hline \multirow{2}{*}{ Isotope } & \multicolumn{2}{|c|}{ Mass Limit (kg) } & \multicolumn{2}{c|}{ Equivalence Factor } \\
\cline { 2 - 5 } & $\begin{array}{c}\mathrm{H}_{2} \mathrm{O}^{\mathrm{h}} \\
\text { Reflector }\end{array}$ & $\begin{array}{c}\mathrm{SS}^{\mathrm{i}} \\
\text { Reflector }\end{array}$ & $\begin{array}{c}\mathrm{H}_{2} \mathrm{O}^{\mathrm{h}} \\
\text { Reflector }\end{array}$ & $\begin{array}{c}\mathrm{SS}^{\mathrm{i}} \\
\text { Reflector }\end{array}$ \\
\hline${ }^{238 \mathrm{Pu}}$ & 6.10 & 4.58 & 0.90 & 1.01 \\
$239 \mathrm{Pu}$ & 5.45 & 4.62 & 1.00 & 1.00 \\
$240 \mathrm{Pu}$ & 29.70 & 18.56 & 0.19 & 0.25 \\
${ }^{241} \mathrm{Pu}$ & 5.45 & 5.22 & 1.00 & 0.89 \\
${ }^{242} \mathrm{Pu}$ & 51.00 & 41.77 & 0.11 & 0.12 \\
${ }^{241} \mathrm{Am}$ & 89.13 & 54.47 & 0.07 & 0.09 \\
\hline
\end{tabular}

i A 20-cm thick type 304 stainless steel reflector, density equals $7.92 \mathrm{~g} / \mathrm{cm}^{3}, 19 \mathrm{wt} \% \mathrm{Ni}, 2 \mathrm{wt} \% \mathrm{Mn}, 69.5 \% \mathrm{Fe}$, and $9.5 \mathrm{wt} \% \mathrm{Cr}{ }^{14}$ 


\section{CONCLUDING REMARKS}

Equivalence relations for seven binary combinations of nuclides were calculated. The systems analyzed included aqueous spheres, homogeneous metal spheres, and metal ball-and-shell configurations, all surrounded by an effectively infinite stainless steel or water reflector. Comparison of the equivalence calculations with the rule-of-fractions showed conservative agreement for aqueous solutions, and both conservative and non-conservative agreement for the metal homogenous sphere systems. The majority of cases with metal ball-and-shell configurations were found to be non-conservative. Equivalence factors for the aqueous solutions and homogeneous metal spheres were calculated. The equivalence factors for the nonconservative metal homogeneous sphere systems were adjusted so that the equivalence factors were conservative. No equivalence factors were calculated for the ball-and-shell systems since the SARP assumes that only homogeneous or uniformly distributed material will be shipped in the 9972-9975 shipping casks, and an unnecessarily conservative critical mass may result if the ball-and-shell configurations are included. Confirmation of these equivalence factors for higher order systems of isotopes is underway. 


\section{REFERENCES}

1. 10 CFR Energy, Parts 51 to 199, (January 1, 1988).

2. K. A. Niemer, SARP Equivalency Relations (U), N-CLC-A-00013 (1994).

3. ANSI/ANS-8.15, American National Standard for Nuclear Criticality Control of Special Actinide Elements, American Nuclear Society, La Grange Park, IL, (1981).

4. T. G. Williamson, Equivalency Relations for Transuranic Nuclides - JOSHUA 70 Cross Sections (U), WSRC-TR-94-071 (February 25, 1994).

5. N. M. Greene, J. W. Arwood, R. Q. Wright, and C. V. Parks, The LAW Library - A Multigroup Cross Section Library for Use in Radioactive Waste Analysis Calculations, ORNL/TM-12370 (August 1994).

6. R. L. Frost, Validation of the LAW 44 Group Library for Plutonium Metal Systems (U), SRT-CMA-940026 (May 17, 1994).

7. R. L. Frost, Validation of the LAW 44 Group Library for Highly Enriched Uranium Metal Systems (U), SRT-CMA-940018 (April 26, 1994).

8. T. G. Williamson, Validation of the LAW 44 Group Library for Uranium-235 Aqueous Solutions Spheres (U), N-CLC-A-00007 (1994).

9. K. A. Niemer, Validation of LAW 44-Energy Group Library for Plutonium Nitrate Solutions (U), SRT-CMA-940028.

10. N. M. Greene, W. E. Ford, L. M. Petrie, J. W. Arwood, AMPX-77: A Modular Code System for Generating Coupled Multigroup Neutron-Gamma Cross-Section Libraries from $E N D F / B-I V$ and/or $E N D F / B-V$, ORNL/CSD/TM-283 (October 1992).

11. R. D. O'Dell, F. W. Brinkley Jr., D. R. Marr, and R. E. Alcouffe, Revised Users Manual for ONEDANT: A Code Package for One-Dimensional, Diffusion-Accelerated, Neutral-Particle Transport, LA-10049-M and CCC-547 (1990).

12. ANSI/ANS-8.1, American National Standard for Nuclear Criticality Safety in Operations with Fissionable Materials Outside Reactors, American Nuclear Society, La Grange Park, IL, (1981).

13. H. C. Paxton and N. L. Pruvost, Critical Dimensions of Systems Containing ${ }^{235} \mathrm{U},{ }^{239} \mathrm{Pu}$, and ${ }^{233}$ U, 1986 Revision, LA-10860-MS, Los Alamos National Laboratory (July 1987).

14. R. M. Westfall, Critical Masses for the Even-Neutron-Numbered Transuranium Actinides, Nuclear Science and Engineering, 79:237(1981). 


\section{APPENDIX A: ATOMIC NUMBER DENSITIES}

Atomic number density $=N=\frac{.60221 * \mathrm{gm} / \mathrm{cm}^{3}}{A}[\mathrm{~atm} / \mathrm{b}-\mathrm{cm}]$ where $A$ is the atomic mass

\section{Aqueous Solutions}

Mass of nuclide $i=m_{i}=f_{i}{ }^{*} M_{i}[\mathrm{~g}]$,

where $M_{i}$ is the critical mass of nuclide $i$, and $f_{i}$ is the fraction of critical mass

Volume of nuclide $i=V_{i}=\frac{m_{i}}{C S_{i}}[1]$,

where $C S_{i}$ is the critical concentration of nuclide $i$.

Volume of mixture $=V_{\text {Tot }}=\sum_{i} V_{i}[1]$.

Radius $=R=\left(\frac{3 V_{\text {Tot }} * 1000}{4 \pi}\right)^{1 / 3}[\mathrm{~cm}]$.

Concentration of nuclide $i=C_{i}=\frac{m_{i}}{V_{\text {Tot }}}\left[\mathrm{g} / \mathrm{cm}^{3}\right]$.

Concentration of $\mathrm{H}_{2} \mathrm{O}=C_{\mathrm{H}_{2} \mathrm{O}}=\left(1-\sum_{i} \frac{C_{i}}{\rho_{i}}\right) \rho_{\mathrm{H}_{2} \mathrm{O}}\left[\mathrm{g} / \mathrm{cm}^{3}\right]$,

where $\rho$ is the density.

Atomic number density of nuclide $i=N_{i}=\frac{.60221 * C_{i}}{A_{i}}[\mathrm{~atm} / \mathrm{b}-\mathrm{cm}]$.

Atomic number density of $\mathrm{O}=N_{\mathrm{O}}=N_{\mathrm{H}_{2} \mathrm{O}}=\frac{.60221^{*} C_{\mathrm{H}_{2} \mathrm{O}}}{A_{\mathrm{H}_{2} \mathrm{O}}}[\mathrm{atm} / \mathrm{b}-\mathrm{cm}]$

Atomic number density of $\mathrm{H}=N_{H}=2 N_{H_{2} O}[\mathrm{~atm} / \mathrm{b}-\mathrm{cm}]$. 


\section{Metal Systems}

\section{Homogeneous metal spheres}

Mass of nuclide $i=m_{i}=f_{i}^{*} M_{i}[\mathrm{~g}]$,

where $M_{i}$ is the critical mass of nuclide $i$, and $f_{i}$ is the fraction of critical mass

Volume of nuclide $i=V_{i}=\frac{m_{i}}{\rho_{i}}\left[\mathrm{~cm}^{3}\right]$,

where $\rho_{i}$ is the density of nuclide $i$.

Volume of mixture $=V_{\text {Tot }}=\sum_{i} V_{i}\left[\mathrm{~cm}^{3}\right]$.

Radius of homogeneous sphere $=R=\left(\frac{3 V_{\text {Tot }}}{4 \pi}\right)^{1 / 3}[\mathrm{~cm}]$.

Concentration of nuclide $i=C_{i}=\frac{m_{i}}{V_{\text {Tot }}}\left[\mathrm{g} / \mathrm{cm}^{3}\right]$.

Atomic number density of nuclide $i=N_{i}=\frac{.60221^{*} C_{i}}{A_{i}}[\mathrm{~atm} / \mathrm{b}-\mathrm{cm}]$

Metal ball-and-shells

Mass of nuclide $i=m_{i}=f_{i}^{*} M_{i}[\mathrm{~g}]$,

where $M_{i}$ is the critical mass of nuclide $i$, and $f_{i}$ is the fraction of critical mass

Volume of nuclide $i=V_{i}=\frac{m_{i}}{\rho_{i}}\left[\mathrm{~cm}^{3}\right]$,

where $\rho_{i}$ is the density of nuclide $i$.

Radius of ball $b=R_{b}=\left(\frac{3 V_{b}}{4 \pi}\right)^{1 / 3}[\mathrm{~cm}]$.

Outer radius of shell $s=R_{s}=\left(\frac{3 \sum_{i} V_{i}}{4 \pi}\right)^{1 / 3}[\mathrm{~cm}]$

Atomic number density of nuclide $i=N_{i}=\frac{.60221^{*} \rho_{i}}{A_{i}}[\mathrm{~atm} / \mathrm{b}-\mathrm{cm}]$. 
Water Reflector

$$
\begin{aligned}
& N_{O}=N_{\mathrm{H}_{2} \mathrm{O}}=\frac{.60221^{*} \rho_{\mathrm{H}_{2} \mathrm{O}}}{A_{\mathrm{H}_{2} \mathrm{O}}}[\mathrm{atm} / \mathrm{b}-\mathrm{cm}] \\
& N_{H}=2 N_{\mathrm{H}_{2} \mathrm{O}}[\mathrm{atm} / \mathrm{b}-\mathrm{cm}]
\end{aligned}
$$

\section{Stainless Steel Reflector}

Type 304L stainless steel reflector, density $=7.92 \mathrm{~g} / \mathrm{cm}^{3}, 19 \mathrm{wt} \% \mathrm{Ni}, 2 \mathrm{wt} \% \mathrm{Mn}, 69.5 \% \mathrm{Fe}$, and $9.5 \mathrm{wt} \% \mathrm{Cr} .{ }^{14}$

$$
N_{i}=\frac{.60221 * w t_{i} \% * \rho_{S S}}{A_{i}}[\mathrm{~atm} / \mathrm{b}-\mathrm{cm}]
$$

All atomic number densities used in this analysis are listed in reference 2. 


\section{APPENDIX B: DATA FOR MIXTURES WITH H2O REFLECTOR}

Table B-1 lists the isotopes and type of systems initially analyzed with a 20-cm $\mathrm{H}_{2} \mathrm{O}$ reflector. These mixtures were analyzed using a constant density for all the isotopes of an element, no density adjustments were performed for isotopic variations. Tables B-2 and B-3 list the critical radii and masses for isotopes listed in Table B-1. Tables B-4 to B-8 list the calculated $\mathrm{k}_{\mathrm{eff}}$ 's, the rule-of-fractions (ROF) values, and the differences between the $k_{\text {eff }}$ and $R O F$ values for mixtures of the isotopes listed in Table B-1. Table B-9 and B-10 list the critical radii and masses calculated with isotopic density adjustments. In addition, the isotopes ${ }^{241} \mathrm{Pu}$ and ${ }^{242} \mathrm{Pu}$ were added to the list of isotopes to be analyzed. Tables B-11 and B-12 list the calculated $k_{\text {eff }}$ 's, the rule-of-fractions (ROF) values, and the differences between the $k_{\text {eff }}$ and $R O F$ values for mixtures of ${ }^{239} \mathrm{Pu}-{ }^{241} \mathrm{Pu}$ and ${ }^{239} \mathrm{Pu}-242 \mathrm{Pu}$. Equivalence factors listed in Tables 7-10 of the report were based on the isotopic density adjusted critical masses.

Table B-1. Isotopes and type of systems analyzed with a $20-\mathrm{cm} \mathrm{H}_{2} \mathrm{O}$ reflector.

\begin{tabular}{|c|l|}
\hline \multicolumn{1}{|c|}{ Isotopes } & \multicolumn{1}{c|}{ Type of System } \\
\hline${ }^{235} \mathrm{U}-239 \mathrm{Pu}$ & $\begin{array}{l}\text { Aqueous Sphere }{ }^{\mathrm{b} 1} \\
\text { Metal Homogeneous Sphere } \\
\text { Metal Ball-and-Shell }\end{array}$ \\
\hline${ }^{235 \mathrm{U}-240 \mathrm{Pu}}$ & $\begin{array}{l}\text { Metal Homogeneous Sphere } \\
\text { Metal Ball-and-Shell }\end{array}$ \\
\hline${ }^{239} \mathrm{Pu}-238 \mathrm{Pu}$ & $\begin{array}{l}\text { Metal Homogeneous Sphere } \\
\text { Metal Ball-and-Shell }\end{array}$ \\
\hline${ }^{239} \mathrm{Pu}-240 \mathrm{Pu}$ & $\begin{array}{l}\text { Metal Homogeneous Sphere } \\
\text { Metal Ball-and-Shell }\end{array}$ \\
\hline${ }^{239} \mathrm{Pu}-241 \mathrm{Am}$ & $\begin{array}{l}\text { Metal Homogeneous Sphere } \\
\text { Metal Ball-and-Shell }\end{array}$ \\
\hline
\end{tabular}

b1 The aqueous sphere system was only analyzed for cases which could contain a mixture of two fissile nuclides. All the other cases contain mixtures of fissile and fissionable nuclides. Aqueous mixtures of fissile and fissionable nuclides will be less reactive than an aqueous solution of the fissile nuclide alone. 
Table B-2. Critical radii and masses for isotopes in aqueous mixture with 20-cm $\mathrm{H}_{2} \mathrm{O}$ reflector.

\begin{tabular}{|l|c|c|}
\hline Isotope & Critical Radii (cm) & Critical Mass (g) \\
\hline $235 \mathrm{U}^{\mathrm{b} 2}$ & 15.07 & 774.68 \\
$239 \mathrm{Pu}^{\mathrm{b} 3}$ & 15.93 & 508.82 \\
\hline
\end{tabular}

Table B-3. Critical radii and masses for isotopes in metal systems with a 20- $\mathrm{cm}_{2} \mathrm{O}$ reflector. ${ }^{\text {b4 }}$

\begin{tabular}{|c|c|c|}
\hline Isotope & Critical Radii (cm) & Critical Mass (kg) \\
\hline $235 \mathrm{U}$ & 6.48 & 21.52 \\
$238 \mathrm{Pu}$ & 4.46 & 7.38 \\
$239 \mathrm{Pu}$ & 4.03 & 5.46 \\
$240 \mathrm{Pu}$ & 7.22 & 31.22 \\
$241 \mathrm{Am}$ & 11.58 & 89.13 \\
\hline
\end{tabular}

b2 $235 \mathrm{U}$ critical radius and mass based on $235 \mathrm{U}$ concentration of $54 \mathrm{~g} / 1$, which corresponds to the minimum critical mass for homogenous water-moderated ${ }^{235} \mathrm{U}$ spheres. ${ }^{13}$

b3 $239 \mathrm{Pu}$ critical radius and mass based on ${ }^{239} \mathrm{Pu}$ concentration of $30 \mathrm{~g} / 1$, which corresponds to the minimum critical mass for homogenous water-moderated Pu spheres. ${ }^{13}$

b4 No density adjustments were performed for isotopes. 
Table B-4. Computed $k_{\text {eff }}$ and rule-of-fractions (ROF) values for ${ }^{235} \mathrm{U}_{-2}{ }^{239} \mathrm{Pu}$ mixtures with $\mathrm{H}_{2} \mathrm{O}$ reflector.

\begin{tabular}{|l|r|r|c|c|r|}
\hline & \multicolumn{1}{|c|}{$235 \mathrm{U}$} & \multicolumn{1}{|c|}{${ }^{239} \mathrm{Pu}$} & \multicolumn{1}{c|}{$\mathrm{k}_{\text {eff }}$} & ROF & $\mathrm{k}_{\text {eff-ROF }}$ \\
\hline Aqueous Solutions & $0 \%$ & $100 \%$ & 1.0069 & & \\
& $25 \%$ & $75 \%$ & 1.0046 & 1.0046 & 0.0000 \\
& $50 \%$ & $50 \%$ & 1.0022 & 1.0023 & -0.0001 \\
& $75 \%$ & $25 \%$ & 0.9998 & 0.9999 & -0.0001 \\
& $100 \%$ & $0 \%$ & 0.9976 & & \\
\hline Homogeneous & $0 \%$ & $100 \%$ & 1.0059 & & \\
Metals & $25 \%$ & $75 \%$ & 0.9692 & 1.0052 & -0.0360 \\
& $50 \%$ & $50 \%$ & 0.9726 & 1.0044 & -0.0318 \\
& $75 \%$ & $25 \%$ & 0.9861 & 1.0037 & -0.0176 \\
& $100 \%$ & $0 \%$ & 1.0029 & & \\
\hline U Ball - Pu Shell & $50 \%$ & $50 \%$ & 0.9402 & 1.0044 & -0.0642 \\
Pu Ball - U Shell & $50 \%$ & $50 \%$ & 1.0483 & 1.0044 & 0.0439 \\
\hline
\end{tabular}

Table B-5 Computed $\mathrm{k}_{\text {eff }}$ and rule-of-fractions (ROF) values for ${ }^{235} \mathrm{U}-240 \mathrm{Pu}$ mixtures with $\mathrm{H}_{2} \mathrm{O}$ reflector.

\begin{tabular}{|l|r|r|r|r|r|}
\hline & \multicolumn{1}{|c|}{$235 \mathrm{U}$} & \multicolumn{1}{|c|}{${ }^{240 \mathrm{Pu}}$} & \multicolumn{1}{c|}{ keff } & ROF & k $_{\text {eff-ROF }}$ \\
\hline Homogeneous & $0 \%$ & $100 \%$ & 1.0000 & & \\
Metals & $25 \%$ & $75 \%$ & 1.0503 & 1.0007 & 0.0496 \\
& $50 \%$ & $50 \%$ & 1.0543 & 1.0015 & 0.0529 \\
& $75 \%$ & $25 \%$ & 1.0360 & 1.0022 & 0.0338 \\
& $100 \%$ & $0 \%$ & 1.0029 & & \\
\hline U Ball - Pu Shell & $50 \%$ & $50 \%$ & 0.9624 & 1.0015 & -0.0391 \\
Pu Ball - U Shell & $50 \%$ & $50 \%$ & 1.0958 & 1.0015 & 0.0943 \\
\hline
\end{tabular}


Table B-6. Computed $\mathrm{k}_{\mathrm{eff}}$ and rule-of-fractions (ROF) values for ${ }^{239} \mathrm{Pu}_{2}{ }^{238} \mathrm{Pu}$ mixtures with $\mathrm{H}_{2} \mathrm{O}$ reflector.

\begin{tabular}{|l|r|r|r|r|r|}
\hline & $239 \mathrm{Pu}$ & $238 \mathrm{Pu}$ & k eff & ROF & keff-ROF \\
\hline Homogeneous & $0 \%$ & $100 \%$ & 0.9999 & & \\
Metals & $25 \%$ & $75 \%$ & 1.0261 & 1.0014 & 0.0247 \\
& $50 \%$ & $50 \%$ & 1.0282 & 1.0028 & 0.0254 \\
& $75 \%$ & $25 \%$ & 1.0201 & 1.0043 & 0.0158 \\
& $100 \%$ & $0 \%$ & 1.0058 & & \\
\hline 239 Ball - 238 Shell & $50 \%$ & $50 \%$ & 0.9701 & 1.0028 & -0.0327 \\
238 Ball - 239 Shell & $50 \%$ & $50 \%$ & 1.0568 & 1.0028 & 0.0540 \\
\hline
\end{tabular}

Table B-7. Computed $\mathrm{k}_{\mathrm{eff}}$ and rule-of-fractions (ROF) values for ${ }^{239} \mathrm{Pu}-{ }^{240} \mathrm{Pu}$ mixtures with $\mathrm{H}_{2} \mathrm{O}$ reflector.

\begin{tabular}{|l|r|r|c|c|c|}
\hline & $239 \mathrm{Pu}$ & $240 \mathrm{Pu}$ & keff & ROF & keff-ROF $_{\text {ef }}$ \\
\hline Homogeneous & $0 \%$ & $100 \%$ & 1.0000 & & \\
Metals & $25 \%$ & $75 \%$ & 1.0080 & 1.0014 & 0.0066 \\
& $50 \%$ & $50 \%$ & 1.0071 & 1.0029 & 0.0042 \\
& $75 \%$ & $25 \%$ & 1.0044 & 1.0043 & 0.0001 \\
& $100 \%$ & $0 \%$ & 1.0058 & & \\
\hline 239 Ball - 240 Shell & $50 \%$ & $50 \%$ & 1.0480 & 1.0029 & 0.0451 \\
240 Ball - 239 Shell & $50 \%$ & $50 \%$ & 1.0196 & 1.0029 & 0.0167 \\
\hline
\end{tabular}

Table B-8. Computed $k_{\text {eff }}$ and rule-of-fractions (ROF) values for ${ }^{239} \mathrm{Pu}-{ }^{241} \mathrm{Am}$ mixtures with $\mathrm{H}_{2} \mathrm{O}$ reflector.

\begin{tabular}{|l|r|r|c|c|c|}
\hline & ${ }^{239} \mathrm{Pu}$ & ${ }^{241} \mathrm{Am}$ & k eff & ROF & k eff ROF \\
\hline Homogeneous & $0 \%$ & $100 \%$ & 1.0000 & & \\
Metals & $25 \%$ & $75 \%$ & 0.9724 & 1.0014 & -0.0290 \\
& $50 \%$ & $50 \%$ & 0.9404 & 1.0029 & -0.0625 \\
& $75 \%$ & $25 \%$ & 0.9060 & 1.0043 & -0.0983 \\
& $100 \%$ & $0 \%$ & 1.0058 & & \\
\hline Pu Ball - Am Shell & $50 \%$ & $50 \%$ & 1.0273 & 1.0029 & 0.0244 \\
Am Ball - Pu Shell & $50 \%$ & $50 \%$ & 1.0022 & 1.0029 & -0.0007 \\
\hline
\end{tabular}


Table B-9. Critical radii and masses for isotopes in aqueous mixture with $20-\mathrm{cm}_{2} \mathrm{O}$ reflector.

\begin{tabular}{|l|c|c|}
\hline Isotope & Critical Radii (cm) & Critical Mass (g) \\
\hline${ }^{235} \mathrm{U}^{\mathrm{b} 2}$ & 15.07 & 774.68 \\
${ }^{239} \mathrm{Pu}^{\mathrm{b} 3}$ & 15.93 & 508.82 \\
${ }^{241} \mathrm{Pu}^{\mathrm{b} 5}$ & 12.98 & 275.01 \\
\hline
\end{tabular}

Table B-10. Calculated critical radii and masses for isotopes in metal systems with a 20-cm $\mathrm{H}_{2} \mathrm{O}$ reflector.

\begin{tabular}{|l|c|c|}
\hline Isotope & Critical Radii (cm) & Critical Mass (kg) \\
\hline${ }^{235} \mathrm{U}$ & 6.49 & 21.52 \\
${ }^{238} \mathrm{Pu}$ & 4.47 & 7.41 \\
${ }^{239} \mathrm{Pu}$ & 4.03 & 5.45 \\
${ }^{240} \mathrm{Pu}$ & 7.18 & 30.84 \\
${ }^{241} \mathrm{Pu}$ & 4.07 & 5.67 \\
${ }^{242} \mathrm{Pu}$ & 9.43 & 70.53 \\
${ }^{241} \mathrm{Am}$ & 11.58 & 89.13 \\
\hline
\end{tabular}

b5 $241 \mathrm{Pu}$ critical radius and mass based on Pu concentration of $30 \mathrm{~g} / \mathrm{l}$, which corresponds to the minimum critical mass for homogenous water-moderated Pu spheres. ${ }^{13}$ 
Table B-11. Computed $\mathrm{k}_{\text {eff }}$ and rule-of-fractions (ROF) values for ${ }^{239} \mathrm{Pu}-{ }^{241} \mathrm{Pu}$ mixtures with $\mathrm{H}_{2} \mathrm{O}$ reflector.

\begin{tabular}{|l|r|r|c|c|c|}
\hline & $239 \mathrm{Pu}$ & $241 \mathrm{Pu}$ & $\mathrm{k}_{\text {eff }}$ & ROF & $\mathrm{k}_{\text {eff-ROF }}$ \\
\hline Aqueous & $0 \%$ & $100 \%$ & 1.0098 & & \\
Solutions & $25 \%$ & $75 \%$ & 1.0087 & 1.0104 & -0.0017 \\
& $50 \%$ & $50 \%$ & 1.0090 & 1.0110 & -0.0020 \\
& $75 \%$ & $25 \%$ & 1.0103 & 1.0116 & -0.0013 \\
& $100 \%$ & $0 \%$ & 1.0122 & & \\
\hline Homogeneous & $0 \%$ & $100 \%$ & 0.9994 & & \\
Metals & $25 \%$ & $75 \%$ & 1.0019 & 1.0011 & 0.0008 \\
& $50 \%$ & $50 \%$ & 1.0042 & 1.0028 & 0.0014 \\
& $75 \%$ & $25 \%$ & 1.0065 & 1.0044 & 0.0021 \\
& $100 \%$ & $0 \%$ & 1.0061 & & \\
\hline
\end{tabular}

Table B-12. Computed $k_{\text {eff }}$ and rule-of-fractions (ROF) values for ${ }^{239} \mathrm{Pu}-242 \mathrm{Pu}$ mixtures with $\mathrm{H}_{2} \mathrm{O}$ reflector.

\begin{tabular}{|l|r|r|c|c|c|}
\hline & ${ }^{239} \mathrm{Pu}$ & ${ }^{242} \mathrm{Pu}$ & keff & ROF & k $_{\text {eff-ROF }}$ \\
\hline Homogeneous & $0 \%$ & $100 \%$ & 1.0001 & & \\
Metals & $25 \%$ & $75 \%$ & 1.0509 & 1.0016 & 0.0493 \\
& $50 \%$ & $50 \%$ & 1.0489 & 1.0031 & 0.0458 \\
& $75 \%$ & $25 \%$ & 1.0260 & 1.0046 & 0.0214 \\
& $100 \%$ & $0 \%$ & 1.0061 & & \\
\hline
\end{tabular}




\section{APPENDIX C: DATA FOR MIXTURES WITH STAINLESS STEEL REFLECTOR}

Table C-1 lists the isotopes and type of systems initially analyzed with a 20-cm stainless steel reflector. These mixtures were analyzed using a constant density for all the isotopes of an element, no density adjustments were performed for isotopic variation. Tables C-2 lists the critical radii and masses for isotopes listed in Table C-1. Note that two critical values are listed for ${ }^{239} \mathrm{Pu}$ and ${ }^{240} \mathrm{Pu}$. The differences are due to the inclusion of NITAWL resonance calculations for the isotopes ( $\mathrm{Fe}, \mathrm{Ni}, \mathrm{Cr}, \mathrm{Mn}$ ) in the stainless steel reflector region. These resonance calculations for the isotopes in the stainless steel increased the computed $k_{\text {eff }}$ for the systems, thus reducing the critical mass of the systems. Computations for mixtures of ${ }^{235} \mathrm{U}^{239} \mathrm{Pu}$ (Table $\mathrm{C}-3$ ) and ${ }^{235} \mathrm{U}-240 \mathrm{Pu}$ (Table $\mathrm{C}-4$ ) did not include resonance calculations for the stainless steel; while mixtures of ${ }^{239} \mathrm{Pu}-238 \mathrm{Pu}$ (Table C-5), ${ }^{239} \mathrm{Pu}-{ }^{240} \mathrm{Pu}$ (Table C-6), and ${ }^{239} \mathrm{Pu}-{ }^{241} \mathrm{Am}$ (Table $\mathrm{C}-7)$ did include resonance calculations for the stainless steel. All mixtures included resonance calculations for the fissile and fissionable isotopes. Tables $\mathrm{C}-3$ to $\mathrm{C}-7$ list the calculated $\mathrm{k}_{\mathrm{eff}} \mathrm{s}$, the rule-of-fractions (ROF) values, and the differences between the $k_{\text {eff }}$ and ROF values for mixtures of the isotopes listed in Table C-1. Table C-8 lists the critical radii and masses calculated with isotopic density adjustments. In addition, the isotopes ${ }^{241} \mathrm{Pu}$ and ${ }^{242} \mathrm{Pu}$ were added to the list of isotopes to be analyzed. Tables C-9 and C-10 list the calculated $k_{\text {eff }}$ 's, the rule-of-fractions (ROF) values, and the differences between the $k_{\text {eff }}$ and $R O F$ values for mixtures of ${ }^{239} \mathrm{Pu}-{ }^{241} \mathrm{Pu}$ and ${ }^{239} \mathrm{Pu}-{ }^{242} \mathrm{Pu}$. Equivalence factors listed in Tables 9 and 10 of the report were based on the isotopic density adjusted critical masses and included NITAWL resonance calculations for the isotopes in the stainless steel reflector.

Table C-1. Isotopes and type of systems analyzed with a 20-cm type 304 stainless steel reflector.

\begin{tabular}{|c|l|}
\hline Isotopes & \multicolumn{1}{|c|}{ Type of System } \\
\hline${ }^{235} \mathrm{U}-239 \mathrm{Pu}$ & $\begin{array}{l}\text { Metal Homogeneous Sphere } \\
\text { Metal Ball-and-Shell }\end{array}$ \\
\hline${ }^{235 \mathrm{U}-240 \mathrm{Pu}}$ & $\begin{array}{l}\text { Metal Homogeneous Sphere } \\
\text { Metal Ball-and-Shell }\end{array}$ \\
\hline${ }^{239} \mathrm{Pu}-238 \mathrm{Pu}$ & $\begin{array}{l}\text { Metal Homogeneous Sphere } \\
\text { Metal Ball-and-Shell }\end{array}$ \\
\hline${ }^{239} \mathrm{Pu}-240 \mathrm{Pu}$ & $\begin{array}{l}\text { Metal Homogeneous Sphere } \\
\text { Metal Ball-and-Shell }\end{array}$ \\
\hline${ }^{239} \mathrm{Pu}-241 \mathrm{Am}$ & $\begin{array}{l}\text { Metal Homogeneous Sphere } \\
\text { Metal Ball-and-Shell }\end{array}$ \\
\hline
\end{tabular}


Table C-2. Critical radii and masses for isotopes in metal systems with a 20-cm type 304 stainless steel reflector. ${ }^{\mathrm{c} 1}$

\begin{tabular}{|c|c|c|}
\hline Isotope & Critical Radii (cm) & Critical Mass (kg) \\
\hline $235 \mathrm{U}$ & 6.21 & 18.92 \\
$238 \mathrm{Pu}$ & 3.85 & 4.75 \\
$239 \mathrm{Puc}$ & $3.81 / 3.86$ & $4.62 / 4.77$ \\
$240 \mathrm{Puc2}$ & $6.10 / 6.13$ & $18.89 / 19.13$ \\
$241 \mathrm{Am}$ & 9.83 & 54.47 \\
\hline
\end{tabular}

Table C-3. Computed $\mathrm{k}_{\text {eff }}$ and rule-of-fractions (ROF) values for ${ }^{235} \mathrm{U}-239 \mathrm{Pu}$ mixtures with stainless steel reflector.

\begin{tabular}{|l|r|r|c|c|c|}
\hline & \multicolumn{1}{|c|}{$235 \mathrm{U}$} & \multicolumn{1}{|c|}{$239 \mathrm{Pu}$} & $\mathrm{k}_{\text {eff }}$ & ROF & k $_{\text {eff-ROF }}$ \\
\hline Homogeneous & $0 \%$ & $100 \%$ & 0.9994 & & \\
Metals & $25 \%$ & $75 \%$ & 0.9609 & 1.0010 & -0.0401 \\
& $50 \%$ & $50 \%$ & 0.9650 & 1.0025 & -0.0375 \\
& $75 \%$ & $25 \%$ & 0.9851 & 1.0041 & -0.0190 \\
& $100 \%$ & $0 \%$ & 1.0056 & & \\
\hline U Ball - Pu Shell & $50 \%$ & $50 \%$ & 0.9285 & 1.0025 & -0.0740 \\
Pu Ball - U Shell & $50 \%$ & $50 \%$ & 1.0494 & 1.0025 & 0.0469 \\
\hline
\end{tabular}

Table C-4. Computed $k_{\text {eff }}$ and rule-of-fractions (ROF) values for ${ }^{235} \mathrm{U}-240 \mathrm{Pu}$ mixtures with stainless steel reflector.

\begin{tabular}{|l|r|r|c|c|c|}
\hline & \multicolumn{1}{|c|}{${ }^{235} \mathrm{U}$} & \multicolumn{1}{|c|}{$240 \mathrm{Pu}$} & $\mathrm{k}_{\text {eff }}$ & ROF & $\mathrm{k}_{\text {eff }}$-ROF \\
\hline Homogeneous & $0 \%$ & $100 \%$ & 1.0000 & & \\
Metals & $25 \%$ & $75 \%$ & 1.0328 & 1.0014 & 0.0314 \\
& $50 \%$ & $50 \%$ & 1.0374 & 1.0028 & 0.0346 \\
& $75 \%$ & $25 \%$ & 1.0267 & 1.0042 & 0.0225 \\
& $100 \%$ & $0 \%$ & 1.0056 & & \\
\hline U Ball - Pu Shell & $50 \%$ & $50 \%$ & 1.0158 & 1.0028 & 0.0130 \\
Pu Ball - U Shell & $50 \%$ & $50 \%$ & 1.0373 & 1.0028 & 0.0345 \\
\hline
\end{tabular}

c1 No density adjustments were performed for isotopes.

c2 Note that two critical values are listed for ${ }^{239} \mathrm{Pu}$ and $240 \mathrm{Pu}$ with a stainless steel reflector. The differences are due to the inclusion of NTAWL resonance calculations for the isotopes $(\mathrm{Fe}, \mathrm{Ni}, \mathrm{Cr}, \mathrm{Mn}$ ) in the stainless steel reflector region. Computations for mixtures of ${ }^{235} \mathrm{U}-{ }^{239} \mathrm{Pu}$ and ${ }^{235} \mathrm{U}-240 \mathrm{Pu}$ did not include resonance calculations for the stainless steel, while mixtures of ${ }^{239} \mathrm{Pu}-{ }^{238} \mathrm{Pu},{ }^{239} \mathrm{Pu}-240 \mathrm{Pu}$, and ${ }^{239} \mathrm{Pu}-{ }^{241} \mathrm{Am}$ did include resonance calculations for the stainless steel. All mixtures included resonance calculations for the fissile and fissionable isotopes. 
Table C-5. Computed $\mathrm{k}_{\mathrm{eff}}$ and rule-of-fractions (ROF) values for ${ }^{239} \mathrm{Pu}-{ }^{238} \mathrm{Pu}$ mixtures with stainless steel reflector.

\begin{tabular}{|l|r|r|r|r|r|}
\hline & $239 \mathrm{Pu}$ & $238 \mathrm{Pu}$ & keff & ROF & keff-ROF \\
\hline Homogeneous & $0 \%$ & $100 \%$ & 0.9999 & & \\
Metals & $25 \%$ & $75 \%$ & 1.0039 & 0.9997 & 0.0042 \\
& $50 \%$ & $50 \%$ & 1.0049 & 0.9995 & 0.0054 \\
& $75 \%$ & $25 \%$ & 1.0032 & 0.9993 & 0.0039 \\
& $100 \%$ & $0 \%$ & 0.9991 & & \\
\hline 239 Ball - 238 Shell & $50 \%$ & $50 \%$ & 1.0000 & 0.9995 & 0.0005 \\
238 Ball - 239 Shell & $50 \%$ & $50 \%$ & 1.0064 & 0.9995 & 0.0069 \\
\hline
\end{tabular}

Table C-6. Computed $\mathrm{k}_{\mathrm{eff}}$ and rule-of-fractions (ROF) values for ${ }^{239} \mathrm{Pu}-240 \mathrm{Pu}$ mixtures with stainless steel reflector.

\begin{tabular}{|l|r|r|r|r|r|}
\hline & $239 \mathrm{Pu}$ & $240 \mathrm{Pu}$ & \multicolumn{1}{c|}{$\mathrm{k}_{\text {eff }}$} & \multicolumn{1}{c|}{ ROF } & k $_{\text {eff-ROF }}$ \\
\hline Homogeneous & $0 \%$ & $100 \%$ & 0.9998 & & \\
Metals & $25 \%$ & $75 \%$ & 1.0008 & 0.9998 & 0.0010 \\
& $50 \%$ & $50 \%$ & 0.9997 & 0.9996 & 0.0001 \\
& $75 \%$ & $25 \%$ & 0.9975 & 0.9993 & -0.0019 \\
& $100 \%$ & $0 \%$ & 0.9991 & & \\
\hline 239 Ball - 240 Shell & $50 \%$ & $50 \%$ & 1.0695 & 0.9996 & 0.0699 \\
240 Ball - 239 Shell & $50 \%$ & $50 \%$ & 0.9501 & 0.9996 & -0.0495 \\
\hline
\end{tabular}

Table C-7. Computed $k_{\text {eff }}$ and rule-of-fractions (ROF) values for ${ }^{239} \mathrm{Pu}-{ }^{241} \mathrm{Am}$ mixtures with stainless steel reflector.

\begin{tabular}{|l|r|r|c|c|c|}
\hline & ${ }^{239} \mathrm{Pu}$ & ${ }^{241} \mathrm{Am}$ & $\mathrm{k}_{\text {eff }}$ & ROF & k $_{\text {eff-ROF }}$ \\
\hline Homogeneous & $0 \%$ & $100 \%$ & 1.0000 & & \\
Metals & $25 \%$ & $75 \%$ & 0.9807 & 0.9998 & -0.0191 \\
& $50 \%$ & $50 \%$ & 0.9578 & 0.9996 & -0.0418 \\
& $75 \%$ & $25 \%$ & 0.9364 & 0.9993 & -0.0629 \\
& $100 \%$ & $0 \%$ & 0.9991 & & \\
\hline Pu Ball - Am Shell & $50 \%$ & $50 \%$ & 1.0466 & 0.9996 & 0.0470 \\
Am Ball - Pu Shell & $50 \%$ & $50 \%$ & 0.9248 & 0.9996 & -0.0748 \\
\hline
\end{tabular}


Table C-8. Calculated critical radii and masses for isotopes in metal systems with a 20-cm type 304 stainless steel reflector.

\begin{tabular}{|l|c|c|}
\hline Isotope & Critical Radii $(\mathrm{cm})$ & Critical Mass $(\mathrm{kg})$ \\
\hline${ }^{235} \mathrm{U}$ & 6.13 & 18.15 \\
${ }^{238} \mathrm{Pu}$ & 3.86 & 4.77 \\
${ }^{239} \mathrm{Pu}$ & 3.82 & 4.62 \\
${ }^{240} \mathrm{Pu}$ & 6.07 & 18.72 \\
${ }^{241} \mathrm{Pu}$ & 3.96 & 5.22 \\
${ }^{242} \mathrm{Pu}$ & 7.92 & 41.77 \\
${ }^{241} \mathrm{Am}$ & 9.83 & 54.47 \\
\hline
\end{tabular}

Table C-9. Computed $k_{\text {eff }}$ and rule-of-fractions (ROF) values for ${ }^{239} \mathrm{Pu}-{ }^{241} \mathrm{Pu}$ mixtures with stainless steel reflector.

\begin{tabular}{|l|r|r|c|c|c|}
\hline & ${ }^{239} \mathrm{Pu}$ & \multicolumn{1}{|c|}{$241 \mathrm{Pu}$} & k eff & ROF & keff-ROF \\
\hline Homogeneous & $0 \%$ & $100 \%$ & 1.0001 & & \\
Metals & $25 \%$ & $75 \%$ & 0.9999 & 1.0001 & -0.0002 \\
& $50 \%$ & $50 \%$ & 0.9998 & 1.0001 & -0.0003 \\
& $75 \%$ & $25 \%$ & 0.9998 & 1.0001 & -0.0003 \\
& $100 \%$ & $0 \%$ & 1.0001 & & \\
\hline
\end{tabular}

Table C-10. Computed $\mathrm{k}_{\mathrm{eff}}$ and rule-of-fractions (ROF) values for ${ }^{239} \mathrm{Pu}{ }^{242} \mathrm{Pu}$ mixtures with stainless steel reflector.

\begin{tabular}{|l|r|r|c|c|c|}
\hline & ${ }^{239} \mathrm{Pu}$ & ${ }^{242} \mathrm{Pu}$ & k eff & ROF & k $_{\text {eff-ROF }}$ \\
\hline Homogeneous & $0 \%$ & $100 \%$ & 1.0001 & & \\
Metals & $25 \%$ & $75 \%$ & 0.9968 & 1.0001 & -0.0033 \\
& $50 \%$ & $50 \%$ & 0.9908 & 1.0001 & -0.0093 \\
& $75 \%$ & $25 \%$ & 0.9837 & 1.0002 & -0.0165 \\
& $100 \%$ & $0 \%$ & 1.0002 & & \\
\hline
\end{tabular}

